\title{
PENGURANGAN NITROGEN PADA LIMBAH CAIR TEROLAH INDUSTRI PENYAMAKAN KULIT MENGGUNAKAN SISTEM WETLAND BUATAN
}

\section{NITROGEN REMOVAL IN A CONSTRUCTED WETLAND TREATING TANNERY WASTEWATER EFFLUENT}

\author{
Prayitno*, Muhammad Sholeh \\ Balai Besar Kulit, Karet, dan Plastik, J1.Sokonandi No. 9 Yogyakarta 55166, Indonesia \\ * Penulis korespondensi. Telp.: +62 274 512929, 563939; Fax.: +62 274 563655; \\ E-mail: prayitno_bbkkp@yahoo.com
}

Diterima: 20 Agustus 2014 Direvisi: 30 Oktober 2014 Disetujui: 5 November 2014

\begin{abstract}
Recently constructed wetland have been widely used in wastewater treatment because of its low energy consumption and its simple operation. A research for removing nitrogen in the treated tannery wastewater by using constructed wetland have been conducted. Two unit of constructed wetland were used. Each unit was vegetated with Equisetum hyemale and Echinodorus palaefolius respectively. Both unit were then operated with subsurface flow system by varying the residence time at 3.125; 2.083; and 1.563 days. The results showed that the optimum effectiveness of nitrogen reduction were $83.67 \%$ with a residence time of 3.125 days and $70.29 \%$ with a residence time of 2.083 days for Equisetum hyemale and Echinodorus palaefolius respectively. Nitrogen reduction rate constant of 0.275 by using the formula of the USEPA was only suitable for wetland with Equisetum hyemale with $R^{2}$ of 0.880 .
\end{abstract}

Keywords: constructed wetland, nitrogen removal, Equisetum hyemale, Echinodorus palaefolius.

\begin{abstract}
ABSTRAK
Saat ini wetland buatan sangat luas digunakan untuk pengolahan limbah cair dikarenakan rendahnya energi yang diperlukan dan pengoperasiannya yang sederhana. Penelitian untuk penurunan kadar nitrogen limbah industri kulit terolah dengan menggunakan wetland buatan telah dilakukan. Penelitian dengan menggunakan dua unit wetland buatan dimana masing-masing ditanami dengan tumbuhan bambu air dan melati air. Kedua unit wetland buatan dioperasikan dengan sistem aliran di bawah permukaan dengan memvariasi waktu tinggal berturut-turut 3,$125 ; 2,083$; dan 1,563 hari. Hasil penelitian menunjukan bahwa efektifitas optimum penurunan nitrogen untuk unit wetland dengan tanaman bambu air adalah sebesar 83,67\% dengan waktu tinggal 3,125 hari, sedangkan untuk melati air penurunan nitrogen optimum terjadi pada wetland dengan waktu tinggal 2,083 hari dengan efektifitas penurunan sebesar 70,29\%. Konstanta kecepatan penurunan nitrogen sebesar 0,275 dengan menggunakan formula dari USEPA hanya sesuai untuk wetland dengan tumbuhan bambu air dengan $\mathrm{R}^{2}$ sebesar 0,880 .
\end{abstract}

Kata kunci: wetland buatan, pengurangan nitrogen, bambu air, melati air.

\section{PENDAHULUAN}

Hampir sebagian besar limbah cair baik limbah cair yang berasal dari industri, rumah tangga, maupun industri pertanian mengandung bahan pencemar nitrogen. Apabila tidak dikendalikan, bahan pencemar ini akan memacu eutrofikasi yang memberikan efek negatif pada lingkungan perairan seperti terganggunya kehidupan biota air dikarenakan pertumbuhan lumut atau ganggang yang akan mengkonsumsi oksigen sehingga sediaan oksigen untuk biota air akan berkurang (Kim \& George, 2012).

Industri penyamakan kulit adalah indusri yang mengolah kulit mentah menjadi kulit tersamak dengan melalui beberapa tahapan proses. Setiap tahapan tersebut menggunakan sejumlah besar bahan kimia dan air, sehingga limbah yang berasal dari industri penyamakan kulit menjadi sangat 
kompleks dan berpotensi mencemari lingkungan apabila tidak dilakukan pengolahan sebelum dibuang ke badan air. Salah satu kandungan limbah cair industri penyamakan kulit adalah nitrogen. Cemaran ini berasal dari degradasi protein yang ada di kulit maupun dari bahan kimia yang digunakan pada proses penghilangan kapur yang menggunakan garam amonium. Menurut Calheiros et al. (2007) kadar nitrogen pada limbah cair industri penyamakan kulit berkisar antara $75-135 \mathrm{mg} / \mathrm{l}$, sedangkan yang disyaratkan oleh Menteri Negara Lingkungan Hidup (1995) nilai ambang batas nitrogen yang diperbolehkan dibuang ke badan air adalah $10 \mathrm{mg} / \mathrm{l}$.

Penanganan limbah cair industri penyamakan kulit yang ada saat ini masih dilakukan dengan cara konvensional yaitu menggunakan cara lumpur aktif. Penggunaan metode lumpur aktif memberikan efektivitas pengurangan yang baik untuk limbah dengan kandungan bahan karbon organik, namun untuk kandungan nitrogen penurunannya masih cukup kecil. Menurut Queiroz et al. (2011), pemecahan nitrogen pada proses pengolahan air limbah secara konvensional melalui dua tahap proses reaksi yaitu nitrifikasi dan denitrifikasi. Proses nitrifikasi memerlukan oksigen (kondisi aerob), sedangkan denitrifikasi memerlukan kondisi tanpa oksigen (anaerob), sehingga adanya aerasi akan menghambat proses denitrifikasi sebagai akibat nitrogen dalam effluent masih tinggi. Untuk itu perlu adanya pengolahan lebih lanjut sebagai pengolahan tersier. Salah satunya adalah dengan menggunakan teknologi wetland.

Wetland dapat didefinisikan sebagai suatu area yang tergenangi air secara intermiten dengan kedalaman air tipikal 0,2-0,6 m (Lee et al., 2009) yang mendukung pertumbuhan tanaman air emergent, dibedakan menjadi dua wetland yaitu natural wetland (wetland alami) dan constructed wetland (wetland buatan) (Vymazal, 2010). Keuntungan sistem wetlanddibandingkan dengan cara pengolahan limbah secara konvensional diantaranya adalah sangat ekonomis, efektif, mudah dalam operasinya, dan tidak memerlukan teknologi yang tinggi, serta dapat digunakan untuk pengolahan bermacam-macam limbah cair (Lee et al., 2009). Menurut Lavrova and Koumanova (2013), wetland buatan dalam pengoperasiannya dibedakan menjadi dua tipe, yaitu wetland dengan aliran di atas permukaan tanah (free water surface/FWS system), dimana air limbah mengalir menggenang di atas permukaan media tanam dan wetland dengan aliran dibawah permukaan tanah (sub-surface flow/SSF system). Pada sistem SSF air limbah mengalir secara perlahan melalui tanaman yang ditanam pada media berpori, misalnya gravel, kerikil, dan tanah. Tanaman melalui akar rhizoma yang mentransfer oksigen kedalam media subsurface dan menciptakan kondisi aerobik. Menurut Kim and George (2012) proses pengolahan air limbah terjadi melalui proses filtrasi, absorpsi oleh mikroorganisme dan adsorpsi polutan oleh tanah. Pengurangan bahan organik pada sistem SSF dibatasi oleh dua faktor yaitu waktu tinggal dan transfer $\mathrm{O}_{2}$ (Borkar \& Mahatme, 2011). Salah satu keuntungan wetland dengan sistem aliran dibawah permukaan media (SSF) adalah tumbuhan yang dapat beradaptasi lebih bervariasi sehingga dapat digunakan sebagai taman dengan estetika yang baik (Prayitno \& Sholeh, 2014). SSF terbagi menjadi aliran horizontal dan vertikal (Pelissari et al., 2014).

Wetland buatan menurut Lee et al. (2009) dapat dinyatakan sebagai bioreaktor kompleks yang terjadi proses fisika, kimia dan biologi dengan gabungan mikrobia, tanaman air dan endapan sedimen. Terdapat beberapa jenis tanaman yang dapat digunakan untuk wetland buatan. Debing et al. (2010) menggunakan tumbuhan Typha angustata, Phragmites communis, dan Scirpus validus untuk menurunkan COD, total nitrogen, dan fosfor pada limbah rumah tangga. Calheiros et al. (2009) menggunakan tanaman Typha latifolia, Phragmintes australis, Stenotaphrum secundatum, dan Iris pseudocorous untuk mengolah limbah industri penyamakan kulit. Borkar and Mahatme (2011) menggunakan tanaman Typha orientalis untuk mengolah limbah cair rumah tangga dengan wetland sistem aliran vertikal. Prayitno (2013) menggunakan taman tanaman air dengan tumbuhan melati air dengan sistem SSF digunakan untuk menurunkan COD dan BOD dari limbah cair terolah industri penyamakan kulit. Dengan cara yang sama telah dilakukan penelitian menggunakan tanaman bambu air untuk meningkatkan kualitas air limbah terolah industri penyamakan kulit khususnya untuk parameter COD, BOD, sulfida, TSS dan krom (Prayitno \& Sholeh, 2014). Afrous et al. (2010) menggunakan wetland dengan tanaman Phragmintes australis, Typha latifolia dan Bulrush untuk mengakumulasi dan mengambil nitrogen dan fosfor dari limbah domestik, 


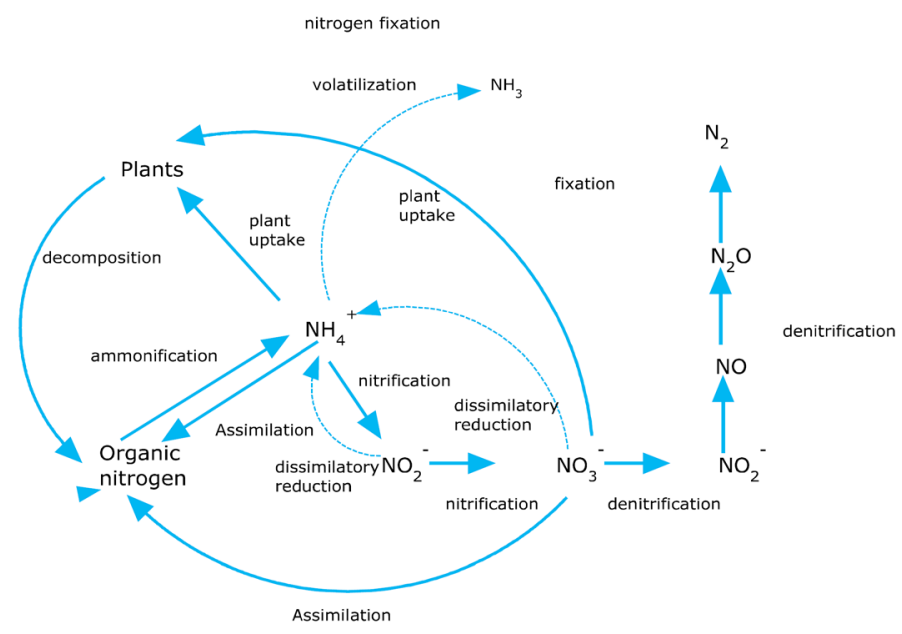

Gambar 1. Transformasi pengurangan nitrogen pada wetland (Saeed \& Sun, 2012).

sedangkan penggunaan wetland buatan untuk penanganan limbah industri kulit telah dilakukan oleh Calheiros et al. (2007).

Penggunaan wetland buatan untuk menurunkan kandungan limbah nitrogen telah banyak dilakukan. Menurut Kim and George (2012), wetland buatan dengan tanaman Scirpus validus dan Typha latifolia dapat menurunkan kadar nitrogen sampai dengan $47 \%$ untuk limbah pembibitan tanaman yang banyak menggunakan bahan kimia. Dibandingkan dengan penanganan limbah secara konvensional, penggunaan wetland memberikan efektivitas pengurangan nitrogen yang lebih tinggi (Xu-jie, 2013), Menurut Debing et al. (2010), wetland dengan tanaman Phragmintes australis, Typha agustata, dan Scirpus validus dapat menurunkan kandungan nitrogen limbah rumah tangga sampai 44,68\%, sedangkan Gerth et al. (2010) menyatakan bahwa wetland dapat digunakan untuk penanganan sekunder limbah industri kulit dan effluent yang dihasilkan dapat digunakan kembali sehingga dapat menghemat air dari sumber air bersih. Pengurangan nitrogen pada wetland menurut Saeed and Sun (2012) terjadi melalui transformasi seperti disajikan pada Gambar 1.

Pada penelitian ini peningkatan kualitas limbah terolah industri penyamakan kulit untuk bahan pencemar nitrogen dilakukan menggunakan wetland buatan dengan sistem aliran SSF menggunakan tanaman bambu air (Prayitno \& Sholeh, 2014) yang dibandingkan dengan pengolahan limbah terolah industri penyamakan kulit dengan menggunakan melati air (Prayitno, 2013).

\section{BAHAN DAN METODE Bahan Penelitian}

Bahan terdiri atas tanaman bambu air (Equisetum hyemale), melati air (Echindorus paleafolium), air limbah effluent dari unit pengolahan air limbah salah satu industri kulit di Yogyakarta.

\section{Peralatan Penelitian}

Peralatan penelitian terdiri atas dua unit wetland buatan dengan gambar skema teknis disajikan pada Gambar 2. Dua buah kompartemen wetland dengan dimensi panjang, lebar, dan dalam berturut-turut $3 \mathrm{~m}$ x $1 \mathrm{~m} \times 1 \mathrm{~m}$, dan media yang terdiri atas beberapa lapisan, yaitu dari atas ke bawah berturut-turut adalah pasir, ijuk, kerikil, dan paling bawah koral. Effluent akan keluar melalui pipa plastik dibagian bawah kemudian dilewatkan bak yang berisi arang aktif sebelum keluar ke badan air.

\section{Metode Penelitian}

Dalam penelitian ini percobaan dilakukan dengan memvariasikan waktu tinggal 1,563; 2,083; dan 3,125 hari didasarkan pada penelitian dari Karunaratne et al.(2011) yang menggunakan waktu tinggal 3,2793 dan 2,2291 hari. Data didapat dengan menguji efektivitas penurunan $\mathrm{NH}_{3}-\mathrm{N}$ sebelum dan sesudah masuk unit wetland buatan kemudian data yang diperoleh dilakukan analisis statistik untuk membandingkan efektifitas dari ke dua jenis wetland buatan terhadap penurunan kadar $\mathrm{N}$-amonia dengan analisis varian kemudian dilanjutkan analisis LSD. Penelitian ini dilakukan dengan wetland buatan dengan ukuran dan cara 

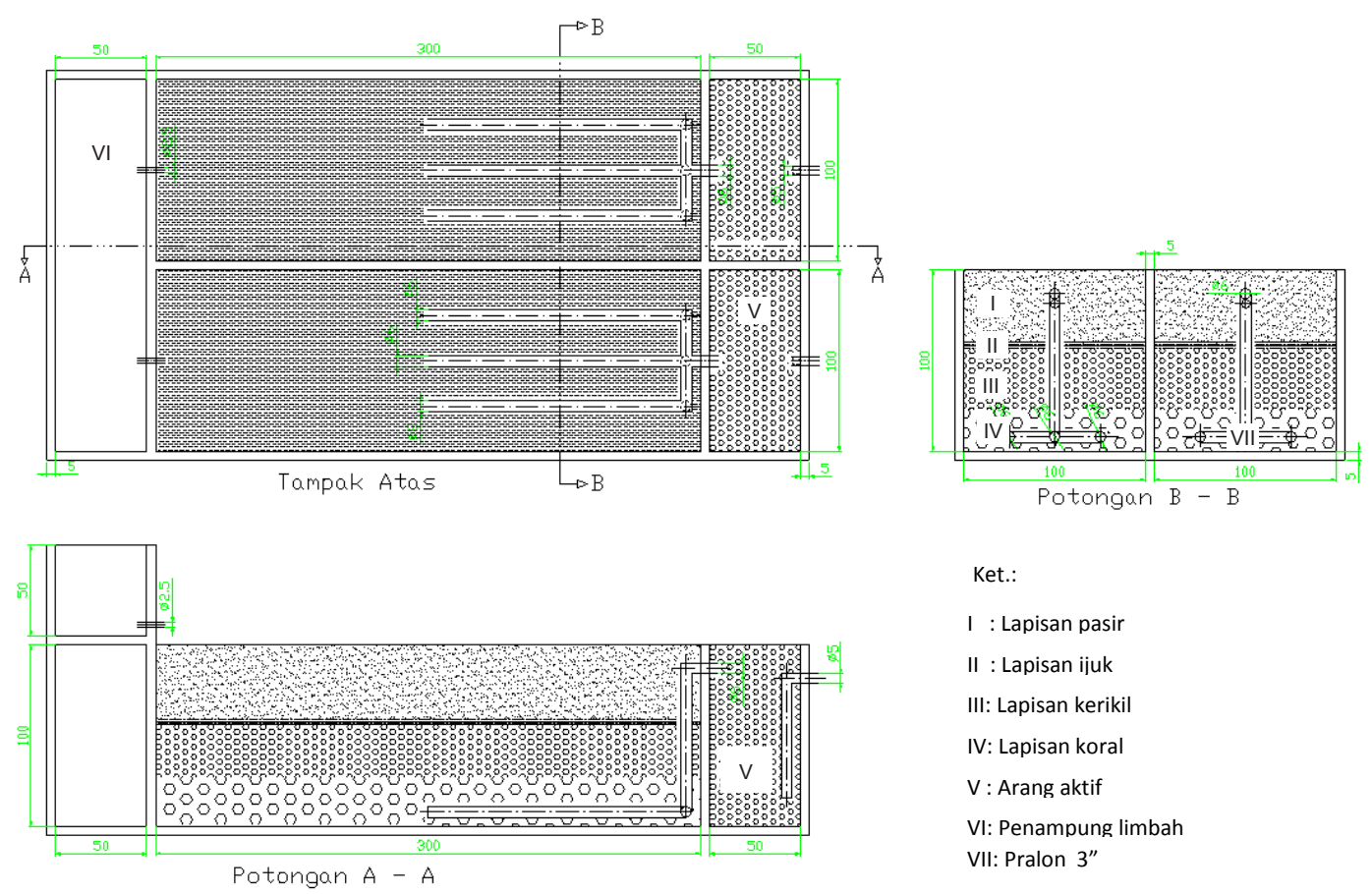

Gambar 2. Skema teknis wetland buatan.

kerja sesuai dengan penelitian Prayitno (2013) dan Prayitno dan Sholeh (2014).

Pengujian kadar nitrogen dilakukan sesuai dengan SNI. 6989.30.2005. Data yang diperoleh dianalisis secara statistik dengan analisis varian dengan taraf kepercayaan 95\% untuk setiap perlakuan dan apabila dijumpai ada beda nyata pada perlakuan dilanjutkan dengan analisa LSD dengan derajat signifikan 5\%. Nilai konstanta untuk penurunan $\mathrm{N}$ dihitung dengan Persamaan (1) berikut (USEPA, 2000; Karunaratne et al., 2011).

$\mathrm{A}_{\mathrm{S}}=\frac{\mathrm{Q} \ln \left(\mathrm{NH}_{0} / \mathrm{NH}_{\mathrm{e}}\right)}{\mathrm{kdn}}$

$\mathrm{A}_{\mathrm{s}}$ adalah luas permukaan wetland $\left(\mathrm{m}^{2}\right)$, $\mathrm{Q}$ adalah debit influent $\left(\mathrm{m}^{3} / \mathrm{d}\right), \mathrm{NH}_{\mathrm{o}}$ adalah konsentrasi $\mathrm{NH}_{3}-\mathrm{N}$ influent $(\mathrm{mg} / \mathrm{l}), \mathrm{NH}_{\mathrm{e}}$ adalah konsentrasi $\mathrm{NH}_{3}-\mathrm{N}$ effluent $(\mathrm{mg} / \mathrm{l}), \mathrm{d}$ adalah kedalaman cairan limbah dalam wetland $(\mathrm{m}), \mathrm{n}$ adalah porositas media (\%), dan $\mathrm{k}$ adalah konstanta $\left(\mathrm{d}^{-1}\right)$.

Waktu tinggal limbah cair dalam unit wetland (t) didapat dengan persamaan (2) (Prayitno, 2013).

$$
\mathrm{t}=\mathrm{V} / \mathrm{Q}=\mathrm{ndA} / \mathrm{Q}
$$

$\mathrm{V}$ adalah volume unit wetland. Dengan mensubtitusikan persamaan (2) ke (1) diperoleh persamaan (3) berikut. $-\mathrm{kt}=\ln \frac{\mathrm{NH}_{\mathrm{e}}}{\mathrm{NH}_{\mathrm{o}}}$

\section{HASIL DAN PEMBAHASAN}

Hasil penelitian menunjukan adanya kenaikan efektivitas pengurangan N-Amonia seiring dengan bertambahnya waktu tinggal. Pada waktu tinggal 1,$563 ; 2,083$; dan 3,125 hari, terjadi efektivitas penurunan nitrogen berturut-turut $61,79 \%$; 74,97\%; dan $83,67 \%$ untuk wetland buatan dengan tanaman bambu air, sedangkan untuk tanaman melati air kenaikan waktu tinggal akan menaikkan efektivitas penurunan N-Amonia dari $20,70 \%$ pada waktu tinggal 1,563 hari menjadi $70,29 \%$ pada waktu tinggal 2,083 hari kemudian terjadi penurunan dengan naiknya waktu tinggal menjadi $-27,83 \%$ untuk waktu tinggal 3,125 hari seperti disajikan pada Gambar 3. Proses penghilangan nitrogen pada unit wetland dapat melalui beberapa mekanisme berturut-turut secara degradasi oleh mikroorganisme (nitrifikasi dan denitrifikasi), penyerapan oleh tumbuhtumbuhan, adsorpsi media, penguapan, dan reaksi kimia (Lee et al., 2009; Kim \& George, 2012). Dari keseluruhan proses tersebut yang sangat nyata mempengaruhi reaksi pengurangan nitrogen pada wetland adalah proses nitrifikasi dan denitrifikasi (Lavrova \& Koumanova, 2013). 


\section{Nitrifikasi dan Denitrifikasi}

Proses nitrifikasi akan merubah N-Amonia melalui dua tahapan proses, pada tahap pertama $\mathrm{N}$-amonia dioksidasi menjadi nitrit (nitritasi) dan tahapan kedua nitrit diubah menjadi nitrat (nitratasi), proses ini terjadi pada kondisi aerobik (Pramanik et al., 2012; Kyambadde, 2005). Pada kedua tahapan proses tersebut diperlukan dua genus bakteri. Menurut Lee et al. (2009) kedua jenis bakteri tersebut adalah dari genus Nitrosomonas untuk oksidasi amonia dan genus Nitrobacter untuk oksidari nitrit. Persamaan dua tahap reaksi tersebut menurut Kyambadde (2005) adalah sebagai berikut.

Nitritasi:

$$
\begin{aligned}
& 2 \mathrm{NH}_{4}^{+}+3 \mathrm{O}_{2} \stackrel{\text { Bakteri Nitrosomonas }}{\longrightarrow} \\
& 4 \mathrm{H}^{+}+2 \mathrm{H}_{2} \mathrm{O}+2 \mathrm{NO}_{2}
\end{aligned}
$$

Nitratasi:

$$
2 \mathrm{NO}_{2}^{-}+\mathrm{O}_{2} \stackrel{\text { Bakteri Nitrobacter }}{\longrightarrow} 2 \mathrm{NO}_{3}^{-}
$$

Kemudian dilanjutkan dengan proses denitrifikasi yang merupakan proses enzimatik tanpa menggunakan oksigen. Pada proses ini, nitrit dan nitrat akan dipecah menjadi molekul nitrogen yang akan diserap oleh tumbuh-tumbuhan atau nitrogen gas yang akan terlepas ke udara (Lee et al., 2009).

Dari penelitian terlihat semakin lama waktu tinggal, semakin kecil debit effluent dan semakin kecil loading rate, menunjukan penurunan pencemar nitrogen yang semakin tinggi. Debing et al. (2010) menyatakan bahwa pengurangan nitrogen sangat tergantung dari loading rate. Efektivitas penurunan nitrogen dapat terjadi apabila loading rate tidak melebihi $0,274 \mathrm{~g} / \mathrm{m}^{2} /$ hari. Ini dapat diartikan meningkatnya loading rate akan menurunkan waktu tinggal sehingga mengurangi efektivitas pengurangan nitrogen.

Dari hasil penelitian terlihat bahwa meningkatnya waktu tinggal akan meningkatkan efektivitas penurunan nitrogen. Pada penggunaan tanaman melati air peningkatan waktu tinggal akan meningkatkan efektivitas pengurangan nitrogen sampai dengan waktu tinggal 2,083 hari, akan tetapi pada waktu tinggal yang lebih tinggi justru akan terjadi penurunan bahkan terjadi pelepasan nitrogen sehingga effluent dapat lebih tinggi dari influent. Hal tersebut diduga disebabkan oleh adanya pelepasan nitrogen dari akar atau kurang sempurnanya proses denitrifikasi. Kim and George (2012) menyatakan bahwa pada unit wetland pengurangan bahan cemaran melalui beberapa proses diantaranya pemecahan oleh mikrobia dan pengambilan oleh tumbuh-tumbuhan. Naiknya kadar N-Amonia pada penambahan waktu tinggal diduga disebabkan oleh proses nitrifikasi dan denitrifikasi yang kurang sempurna. Akar tumbuhan melati air tidak dapat penetrasi jauh ke dalam (hanya ada dipermukaan) sehingga proses nitrifikasi hanya terjadi pada air limbah yang kontak dengan akar tanaman yang diatas, sehingga proses nitrifikasinya terbatas. Akar tumbuhan akan menjadi media tumbuh dari mikroorganisme yang juga akan mensuplai oksigen yang diperlukan oleh bakteri nitrifikasi, juga penyerapan akar tanaman untuk kandungan nitrogen limbah tidak sampai ke dalam, nitrogen akan terakumulasi dan dilepas kembali ke effluent.

Akar bambu air dapat penetrasi sampai ke dalam sehingga luas kontak dengan limbah akan lebih banyak dan kemampuan penyerapan unsur nitrogen juga akan lebih banyak. Meningkatnya waktu tinggal akan memberikan kesempatan lebih banyak bagi mikroorganisme untuk mendegradasi limbah dan akar tanaman mempunyai kemampuan lebih banyak untuk menyerap nitrogen.

Perhitungan statistik dengan cara faktorial dengan taraf kepercayaan 95\% menunjukan adanya perbedaan nyata untuk faktor waktu tinggal $\mathrm{F}_{\text {hitung=7.99 }}<\mathrm{F}_{\text {tabel }=4.1}$. Hal ini dapat diartikan bahwa naiknya waktu tinggal akan meningkatkan efektivitas penggurangan nitrogen pada unit wetland, khususnya untuk wetland buatan dengan tanaman bambu air, sedangkan untuk tanaman melati air optimal efektifitas pengurangan nitrogen terjadi pada waktu tinggal 2,083 hari.

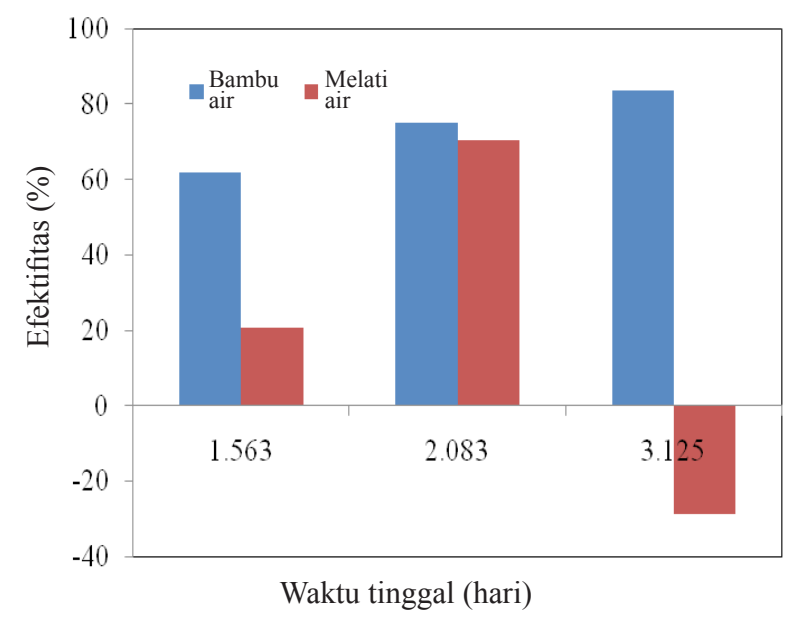

Gambar 3. Grafik efektivitas pengurangan nitrogen vs waktu tinggal 


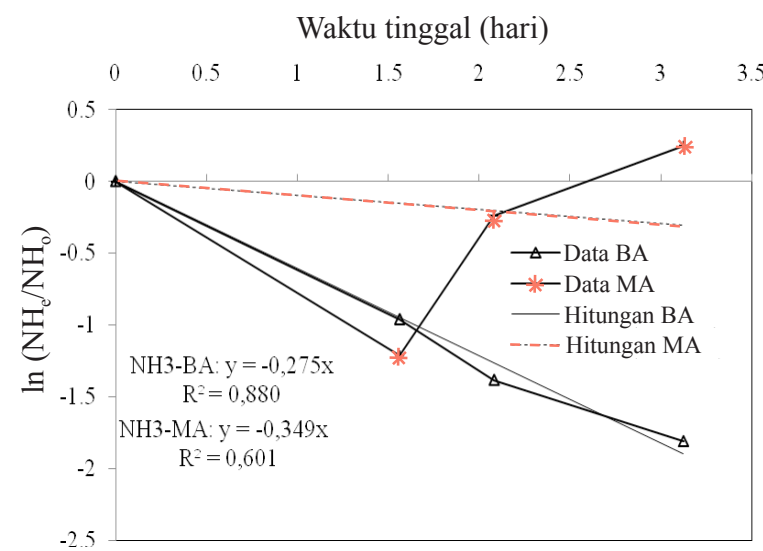

Gambar 4. Linearitas wetland buatan dengan tanaman bambu air dan melati air untuk efektivitas penurunan nitrogen: (BA) bambu air dan (MA) melati air.

\section{Konstanta Reaksi}

Hasil perhitungan konstanta reaksi dengan menggunakan formula dari USEPA (2000) dan Karunaratne et al. (2011) seperti disajikan pada Gambar 4. Konstanta reaksi untuk penurunan nitrogen pada wetland buatan dari kedua jenis tanaman dihitung dengan formulasi dari USEPA menunjukan adanya korelasi positif dengan meningkatnya waktu tinggal dengan kostanta reaksi 0,275 dan nilai $R^{2}=0,880$, sedangkan untuk bambu air tidak menunjukan kelinearan dengan nilai $\mathrm{R}=0,601$. Menurut Karunaratne et al. (2011) perkiraan konstanta kecepatan reaksi pengurangan nitrogen pada wetland untuk total kjehldahl nitrogen sebesar $0,2459 \pm 0,014$.

\section{KESIMPULAN}

Dari hasil penelitian dapat disimpulkan penggunaan wetland dengan tanaman bambu air sangat efektif untuk menurunkan kadar nitrogen pada limbah cair terolah industri penyamakan kulit. Dengan waktu tinggal 3,$125 ; 2,083$ dan 1,563 hari, berturut-turut menunjukan efektivitas penurunan nitrogen sebesar 83,67; 74,97; dan $61,79 \%$. Wetland buatan dengan tanaman melati air pada waktu tinggal 3,125 hari justru terjadi kenaikan kadar $\mathrm{N}$ pada effluent sehingga efektivitas turun menjadi $-27,83 \%$, yang diduga disebabkan kurang optimalnya proses nitrifikasi dan denitrifikasi karena bentuk akar melati air hanya ada dipermukaan, sedangkan dengan waktu tinggal 2,083 dan 1,563 hari berturut-turut efektivitas penurunan nitrogen sebesar 70,59 dan $20,70 \%$. Wetland dengan tanaman bambu air lebih sesuai untuk menurunkan kadar nitrogen dari limbah terolah industri kulit dengan konstanta laju penurunan nitrogen $0,275 \mathrm{~d}^{-1}$.

\section{UCAPAN TERIMA KASIH}

Ucapan terima kasih kami tujukan kepada Kepala Balai Besar dan Kepala Bidang SARS Balai Besar Kulit, Karet, dan Plastik, Yogyakarta atas pengarahannya dan semua fasilitas yang diberikan sehingga penelitian ini dapat terselesaikan.

\section{DAFTAR PUSTAKA}

Afrous, A., Hedayat, N., Liaghat, A., Mohammadpour, M., \& Manshouri, M. (2010). Accumulation and uptake of nitrogen and $\mathrm{P}$ by four species of aquatic plants under arid and semi-arid conditions of Dezful, Iran. World Applied Sciences Journal, 10(8), 886-891.

Borkar. R. P., \& Mahatme, P. S. (2011). Waste water treatment with vertical flow constructed wetland. Internasional Journal of Environmental Sciences, 2(2), 590-603.

Calheiros, C. S., Rangel, A. O., \& Castro, P. M. (2007). Constructed wetland systems vegetated with different plants applied to the treatment of tannery wastewater. Water Research, 41(8P), 1790-1798.

Calheiros, C. S., Rangel, A. O., \& Castro, P. M. (2009). Treatment of industrial wastewater with twostage constructed wetlands planted with Typha latifolia and Phragmites australis. Bioresource Technology, 100(13), 3205-3213.

Debing. J., Baoqing. S., Hong. Z., \& Jianming. H. (2010). Chemical oxygen demand, nitrogen and phosphorus removal by subsueface wetdlands with Phragmites vegetation in defferent model. Engineering Life Science, 10(10), 177-183.

Gerth, A., Kuhne, A., Hebner, A., \& Wilken, D. (2010). Application of Phytotechnologies in developing countries. Asia Pasific Journal Molecular Biology and Biotechnology, 18(1), 43-45.

Kyambadde. J. (2005). Optimizing process for biological nitrogen removal in Nakivubo wetland, Uganda (Thesis). Royal Institute of Technology, Swedia.

Kim, G. S., \& George. D. B. (2012). Removal of nitrogen, phosphorus and prodiamine from a container nursery by a subsurface flow constructed wetland. Journal of Bioremediation and Biodegradation, $7(2), 1-5$.

Karunaratne. S., Wijesiri, B. S., \& Sooriya, V. M. J. (2011). Estimation of reaction rate constant of pollutan removal for subsurface flow constructed wetland treating grey water. In Conference Proceeding of IESL-SSMS Joint International Symposium on Social Management System. Colombo, Srilanka: Society of Social Management 
System.

Lavrova, S., \& Koumanova, B. (2013). Nutrients and organic matter removal in a vertical-flow constructed wetland. Croatia: InTech.

Lee, C. G., Fletcher, T. D., \& Sun, G. (2009). Nitrogen removal in constructed wetland systems. Engineering in Life Sciences, 9(1), 11-22.

Menteri Negara Lingkungan Hidup. (1995). Keputusan Menteri Negara Lingkungan Hidup No.51/ MENLH/10/1995 tentang Baku mutu limbah cair bagi kegiatan industri. Jakarta, Indonesia.

Pelissari, C., Sezerino, P. H., Decezaro, S. T., Wolff, D. B., Bento, A. P., Junior, O. C., \& Philippi, L. S. (2014). Nitrogen transformation in horizontal and vertical flow constructed wetlands applied for dairy cattle wastewater treatment in southern Brazil. Ecological Engineering, 73, 307-310.

Pramanik, B., Fatihah, S., Shahrom, Z., \& Ahmed, E. (2012). Biological aerated filters (BAFs) for carbon and nitrogen removal: A review. Journal of Engineering Science and Technology, 7(4), 428-446.

Prayitno, P. (2013). Pengurangan COD dan BOD limbah cair terolah industri penyamakan kulit menggunakan taman tanaman air dengan tanaman melati air. Majalah Kulit, Karet, dan Plastik, 29(1), 23-28.
Prayitno, P., \& Sholeh. M. (2014). Peningkatan kualitas air libah terolah industri penyamakan kulit menggunakan taman tanaman air dengan tumbuhan bambu air. Majalah Kulit, Karet, dan Plastik, 30(1), 23-28.

Queroz. L. M., Aun. M. V., Morita. D. M., \& Sobrinho. P. A. (2011). Biological nitrogen removal over nitrification/denitritation using phenol as carbon sources. Brazil Journal Chemical Engineering, 28(2), 197-207.

Saeed, T., \& Sun, G. (2012). A review on nitrogen and organic removal mechanisms in subsurface flow constructed wetlands: dependency on environmental parameters, operating conditions and supporting media. Journal of Environmental Management, 112, 429-448.

USEPA (United States Environmental Protection Agency). (2000). Design Manual Constructed Wetland and Aquatic Plant System for Municipal Wastewater Treatment. USA: USEPA.

Vymazal, J. (2010). Constructed wetlands for wastewater treatment. Water, 2, 530-549.

Xu-jie. L. U. (2013). Application of constructed wetland for the nitrogen removal. Journal of Civil Environtment Engineering, 3, 1-3. 
